冒许鹏, 习娇娇,范佳辉,吕荣荣,徐网谷,王智, 李明诗.内蒙古大兴安岭林草交错带景观动态分析.生态学报, 2021,41(21):8623-8634. Mao X P, Diao J J, Fan J H, Lü Y Y, Xu W G, Wang Z, Li M S.Dynamic analysis and prediction of landscape pattern in Daxinganling forest-grass ecotone in the Inner Mongonia.Acta Ecologica Sinica, 2021,41(21):8623-8634.

\title{
内蒙古大兴安岭林草交错带景观动态分析
}

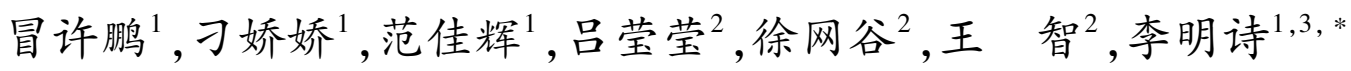 \\ 1 南京林业大学林学院, 南京 210037 \\ 2 生态环境部南京环境科学研究所, 南京 210037 \\ 3 南京林业大学南方现代林业协同创新中心, 南京 210037
}

摘要: 为加强对林草交错带生态系统的科学管理,进一步促林草资源保护与合理利用,迫切需要摸清交错带景观本底并分析其 时空动态演化趋势。以大兴安岭林草交错带为研究对象,选取 2000、2010 年 Landsat 5 TM 影像和 2018 年 Landsat 8 OLI 影像, 利用面向对象的决策树分类算法建立 3 期土地利用数据集,据此分析土地利用动态变化与景观格局演变特征,然后利用状态转 换模拟模型 STSM 模拟研究区 2025 年的土地利用数据。结果表明:(1) 2010 年林地、草地、耕地、湿地、人工表面、盐碱地及荒漠 和过火区面积占比分别为 $46.93 \% 、 31.66 \% 、 5.02 \% 、 13.73 \% 、 1.08 \% 、 1.55 \%$ 和 $0.04 \% ; 2018$ 年分别为 $46.89 \% 、 31.69 \% 、 4.99 \%$ 、 $13.72 \% 、 1.15 \% 、 1.54 \%$ 和 $0.02 \%$ 。(2) 景观尺度上, 2010一-2018 年间林地面积减少 $43.55 \mathrm{~km}^{2}$, 破碎化程度加剧、景观完整性降 低、景观构成愈发复杂; 草地面积增加 $38.11 \mathrm{~km}^{2}$, 其景观完整性升高。(3) 在现行趋势下, 预测 2025 年研究区林地、草地、人工 表面和过火区面积分别增加 92.27、183.21、66.2 $\mathrm{km}^{2}$ 和 $10.25 \mathrm{~km}^{2}$; 耕地、湿地和盐碱地及荒漠面积分别减少 $184.2 、 2.89 \mathrm{~km}$ 和 $164.84 \mathrm{~km}^{2}$ 。林火频发是导致研究区林地面积减少的主因,模拟的过火区面积增加提醒森林管理部门要严控林区用火风险并 增强火灾扑救能力建设。后期“天然林保护”工程和“退牧还草”政策的实施是生态环境改善的主因。在制定区域发展战略时， 需要充分平衡农业生产与城市扩张之间的竞争性,满足区域耕地红线的基本要求。

关键词:林草交错带;土地利用变化; 区域景观格局;STSM 模型

\section{Dynamic analysis and prediction of landscape pattern in Daxinganling forest-grass ecotone in the Inner Mongonia}

\author{
MAO Xupeng ${ }^{1}$, DIAO Jiaojiao ${ }^{1}$, FAN Jiahui ${ }^{1}$, LÜ Yingying ${ }^{2}$, XU Wanggu ${ }^{2}$, WANG Zhi ${ }^{2}$, LI Mingshi ${ }^{1,3, *}$ \\ 1 College of Forestry, Nanjing Forestry University, Nanjing 210037, China \\ 2 Nanjing Institute of Environmental Sciences, Ministry of Ecology and Environment of the People's Republic of China, Nanjing 210037, China \\ 3 Co-Innovation Center for Sustainable Forestry in Southern China, Nanjing Forestry University, Nanjïng 210037, China
}

\begin{abstract}
To strengthen the scientific ecosystem management in the forest-grass ecotone and to further promote forest and grass resources protection and rational utilization, there is an urgent need to ascertain landscape baseline and its spatiotemporal evolution trend. In this study, the forest-grass ecotone of Daxinganling in the Inner Mongonia was chosen as the research area. Based on the Landsat 5 TM images acquired in 2000, 2010 and Landsat 8 OLI images acquired in 2018, the object-oriented decision tree classification algorithm was applied to create the land use datasets first. Next, the dynamic characteristics of land use and landscape pattern evolution were analyzed, followed by a simulation analysis based on the State and Transition Simulation Model ( STSM) to project the current land use trend of the study area to 2025. The results

基金项目:生态环境部生物多样性调查、观测和评估项目(2019-2023 年); 国家自然科学基金项目 (31971577); 江苏高校优势学科建设项目 (PAPD)

收稿日期: 2020-06-19; 网络出版日期: 2021-07-05

* 通讯作者 Corresponding author.E-mail: nfulms@ njfu.edu.cn
\end{abstract}


showed that: (1) in 2010, the area proportion of forest, grassland, cropland, wetland, urban, saline-alkali lands and desert, and burned area was at 46.93\%, 31.66\%, 5.02\%, 13.73\%, 1.08\%, 1.55\%, and 0.04\%, respectively. In 2018, it was at $46.89 \%, 31.69 \%, 4.99 \%, 13.72 \%, 1.15 \%, 1.54 \%$ and $0.02 \%$, respectively. (2) At the landscape scale, during the period of 2010-2018, the forest dropped by $43.55 \mathrm{~km}^{2}$ and its fragmentation severity increased, accompanied by a decreased integrity of forest landscape and a more complex composition of forest landscape, while grassland increased by $38.11 \mathrm{~km}^{2}$ and its integrity of landscape improved. (3) Following the current trend, the projected area of forest, grassland, urban and burned area in 2025 from STSM would increase by $92.27,183.21,66.2 \mathrm{~km}^{2}$ and $10.25 \mathrm{~km}^{2}$, respectively, while cropland, wetland, saline-alkali lands and desert would decrease by $184.2,2.89 \mathrm{~km}^{2}$ and $164.84 \mathrm{~km}^{2}$, respectively. In the study of large-scale land cover prediction with historical data, the prediction accuracy of STSM model was better than that of Ca-Markov model. Frequent occurrence of forest fire was primarily responsible for the reduction of forest area in the study area. The simulated increase in burned area informed the forest management department of strictly controlling fire risk in the forested area and escalating the capability construction of fire suppression. And the implementation of Natural Forest Protection Project and the Grain for Green Project in the later period was the leading trigger for the improvement of ecological environment. When developing a regional development strategy, the competition between the agricultural production and urban sprawl must be compromised to satisfy the basic requirement of the regional red line for arable lands.

Key Words : forest grass ecotone; land use change; regional landscape pattern; STSM model

气候变化与人类活动对地表过程的影响日益加剧, 土地利用变化引起的景观格局演变和生态系统变化研 究已成当前热点 ${ }^{[1-2]}$ 。大兴安岭林草交错生态脆弱区受气候变化、过度放牧和旅游开发等影响, 当地生物多 样性减少、草原不断退化 ${ }^{[3-5]}$ 。因此, 加强林草交错带生态系统的本底调查及其动态变化趋势研究, 将有助于 深人理解林草交错带生态系统脆弱性的成因,并进一步提升林草资源保护与合理利用水平 ${ }^{[6-7]}$ 。

当前, 土地利用和景观的时空格局变化及驱动力分析、生态环境效应对土地利用变化和景观格局演变的 响应以及土地利用系统和生态服务系统之间的相互作用已有较多研究 ${ }^{[8-10]}$ 。例如,马珂等 ${ }^{[11]}$ 基于 Markov 过 程原理, 在景观尺度下分析了新疆乌苏绿洲的生态环境动态过程与发展趋势。吕乐婷等 ${ }^{[12]}$ 对东江流域 1990-2016 年的景观格局时空变化进行分析并采用 FLUS 模型对未来景观格局进行了预测。叶晶萍等 ${ }^{[13]}$ 运 用遥感生态指数对寻乌水流域 1995-2015 年期间生态环境质量时空演变进行了评价。Keller 等 $^{[14]}$ 应用 InVEST 模型探究了土地利用变化对生态服务功能干扰最小化的途径, 并为未来土地管理提供科学的理论指 导。在景观动态模拟方面, CA-Markov 模型综合了 CA 模型模拟复杂系统行为的能力和 Markov 模型的长期预 测优势, 近年来被国内外学者广泛使用 ${ }^{[15-19]}$ 。Guan 等 ${ }^{[20]}$ 基于 CA-Markov 模型, 对日本佐贺市 2015-2042 年 的土地利用时空格局演变过程进行了有效模拟和预测。而状态转换模拟模型 STSM 主要被运用于大尺度的 城市区域及森林方面的预测研究 ${ }^{[21]}$, 在土地利用模拟方面的应用研究相对较少。

针对当前多数研究中使用的土地覆盖数据精度较低以及对森林长期演变过程中破碎化的空间变化模式 量化不足等问题, 本研究首先采用面向对象的决策树分类, 建立林草交错带高精度土地利用数据,再利用景观 格局指数评估区域景观形状变化、景观破碎化程度、景观异质性程度等,最后利用 STSM 模型对研究区 2025 年土地利用空间格局进行模拟, 以期为制定区域发展战略提供参考。

\section{1 研究区概况}

大兴安岭林草交错带位于内蒙古自治区东北部的呼伦贝尔市, 南北长约 $696 \mathrm{~km}$, 东西宽约 $384 \mathrm{~km}$, 研究 区总面积为 13.43 万平方公里 (图 1)。全区地势为东北方向高, 西南方向低, 属浅山丘陵地带。气候类型为 温带大陆季风气候, 冬季寒冷漫长、夏季短促, 年平均气温 $-2.4^{\circ} \mathrm{C}$, 多年平均降雨量 $358 \mathrm{~mm}$ 。植物生长季为 5 月上旬至 8 月末, 持续 70-100 d。研究区植被分布区系由东向西依次为北方针叶林带-落叶阔叶林带-森林 
草原带-草原带,地带性差异明显。针叶树种主要有兴 安落叶松 (Larix gmelini) 、樟子松 (Pinus sylvestris)、油松 (Pinus tabuliformis) 等, 阔叶树种主要有白华 (Betula platyphylla)、山杨(Populus davidiana) 等, 森林草原代表 建群种有黄花菜 (Hemerocallis minor)、地榆 (Sanguisorba officinalis) 等, 草原代表建群种有大针茅 (Stipa grandis)、克氏针茅(Stipa krylovii) 等。

\section{2 数据来源及研究方法}

\section{1 数据获取}

研究数据主要包括遥感影像数据和实地调查数据。 遥感影像数据为覆盖整个研究区的 Landsat 5 TM 图像 (2000 和 2010 年) 以及 2018 年的 Landsat 8 OLI 图像, 共 36 景。所有数据均是来自 USGS 官方网站 (https:// glovis.usgs.gov/) 提供的地表反射率数据。为保证分类 精度,选择研究区夏季无云或少云的影像数据。其中 2010 年少量影像云量较多,采用对应位置上 2009 或 2011 年同时期影像进行替代。

\section{2 土地利用分类主题}

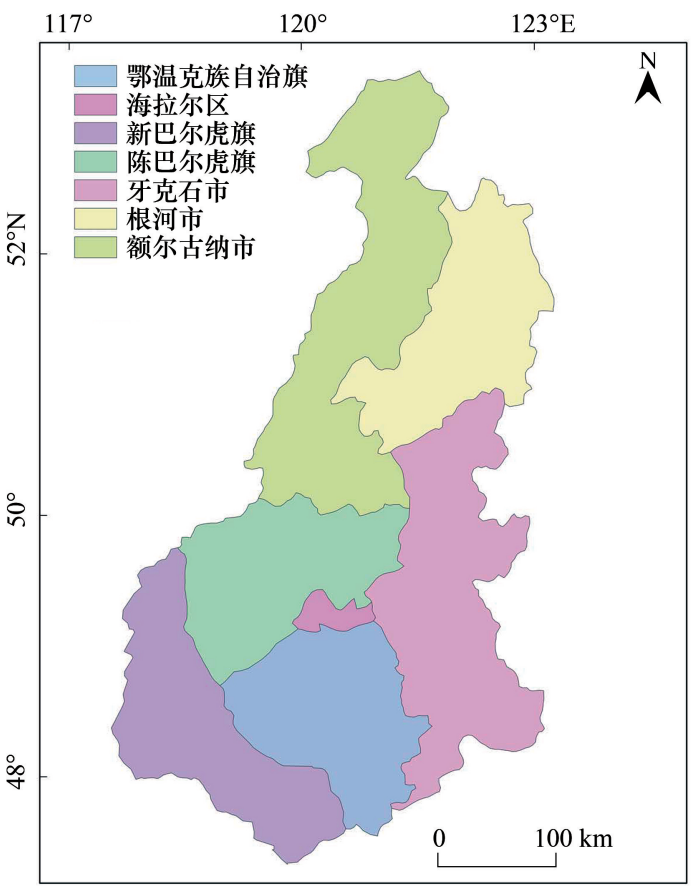

图 1 研究区行政区划图

Fig.1 Administrative divisions of the study area

依据《全国 30 米分辨率土地利用分类系统》,将大 兴安岭地区土地利用类型分为林地、草地、耕地、湿地、人工表面、盐碱地及荒漠和过火区七大类。

2.2.1 间值化处理

图像阈值化是利用图像像素值的频数分布规律, 设定门限值进行像素点分割, 进而得到二值专题图像。 利用修正归一化差异水体指数 (MNDWI), 阈值设定为 0.2 , 区分研究区的水体与非水体。构建归一化植被指 数(NDVI) 检测植被健康状态及活力特征,消除部分辐射及地形误差。阈值设定为 0.2 , 以区分植被与非植被。 两个指数的计算公式见表 1 。

\section{表 1 决策树分类所用图像指数列表}

Table 1 List of the image indexes used in decision trees classification

\begin{tabular}{|c|c|c|}
\hline $\begin{array}{l}\text { 指数 } \\
\text { Index }\end{array}$ & $\begin{array}{l}\text { 计算公式 } \\
\text { Calculation formula }\end{array}$ & $\begin{array}{l}\text { 说明 } \\
\text { Explanation }\end{array}$ \\
\hline $\begin{array}{l}\text { 归一化差异水体指数 (MNDWI) }{ }^{[22]} \\
\text { Modified normalized difference water index }\end{array}$ & MNDWI $=\frac{\rho_{\text {green }}-\rho_{\text {mir }}}{\rho_{\text {green }}+\rho_{\text {mir }}}$ & $\begin{array}{l}\rho_{\text {green }} \text { 为绿光波段光谱反射率; } \rho_{\text {mir }} \text { 为 } \mathrm{TM} \text { 中红外波 } \\
\text { 段光谱反射率, OLI 用短波红外 } 1 \text { 波段光谱反射率 } \\
\text { 代替 }\end{array}$ \\
\hline $\begin{array}{l}\text { 归一化植被指数 (NDVI) }{ }^{[23]} \\
\text { Normalized difference vegetation index }\end{array}$ & NDVI $=\frac{\rho_{\text {nir }}-\rho_{\text {red }}}{\rho_{\text {nir }}+\rho_{\text {red }}}$ & $\begin{array}{l}\rho_{\text {nir }} \text { 为近红外波段光谱反射率; } \rho_{\text {red }} \text { 为红外波段光谱 } \\
\text { 反射率 }\end{array}$ \\
\hline $\begin{array}{l}\text { 比值居民地指数 ( RRI) }{ }^{[24]} \\
\text { Ratio Resident-area Index }\end{array}$ & $\mathrm{RRI}=\frac{\rho_{\text {red }}}{\rho_{\text {nir }}}$ & $\begin{array}{l}\rho_{\text {nir }} \text { 为近红外波段光谱反射率; } \rho_{\text {red }} \text { 为红光波段光谱 } \\
\text { 反射率; 使城市建设用地区域得到增强,去除裸地 }\end{array}$ \\
\hline $\begin{array}{l}\text { 归一化建筑指数 (NDBI) }{ }^{[25-26]} \\
\text { Normalized difference built-up Index }\end{array}$ & NDBI $=\frac{\rho_{\text {mir }}-\rho_{\text {nir }}}{\rho_{\text {mir }}+\rho_{\text {nir }}}$ & $\begin{array}{l}\rho_{\text {mir }} \text { 为 } \mathrm{TM} \text { 中红外波段光谱反射率, OLI 用短波红外 } \\
1 \text { 波段光谱反射率代替; } \rho_{\text {nir }} \text { 为近红外波段光谱反射 } \\
\text { 率; 提取城镇用地 }\end{array}$ \\
\hline $\begin{array}{l}\text { 归一化燃烧率( NBR })^{[27]} \\
\text { Normalized burn ratio }\end{array}$ & $\mathrm{NBR}=\frac{\rho_{\text {nir }}-\rho_{\text {swir }}}{\rho_{\text {nir }}+\rho_{\text {swir }}}$ & $\begin{array}{l}\rho_{\text {nir }} \text { 为近红外波段光谱反射率; } \rho_{\text {swir }} \text { 为短波红外波段 } \\
\text { 光谱反射率; 与林火烈度呈负相关, 取值范围是 }-1 \\
\text { 到 } 1\end{array}$ \\
\hline
\end{tabular}




\subsection{2 基于面向对象的分类}

得到植被和非植被区域后,采用面向对象的决策树分类方法,将非植被区域分为人工表面、过火区和盐碱 地及荒漠, 同时植被区域细分为林地、草地和耕地。由于研究区主要地物的形状及大小各不相同,对应的最优 分割尺度也应不同。在 eCognition 软件中使用 ESP 插件计算最优分割指数,最终确定基准分割尺度为 “30”。 通过对比实验发现,当分割过程中 shape 指数为 0.6 , compactness 指数为 0.5 时各地物分割效果最好。非植被 区域的决策树分类输人特征包括: 归一化火烧指数 (NBR)、比值居民地指数 (RRI) 和归一化建筑指数 (NDBI)。植被区域的决策树分类输人特征包括均值、方差、均匀性、对比度、相异性、熵、二阶矩和相关性等 8 个纹理测度以及缨帽变换 (K-T 变换) 生成的亮度(Brightness)、绿度( Greenness) 和湿度( Wetness)特征。图像 指数的计算公式见表 1 ,所采用的决策树模型如图 2 所示。

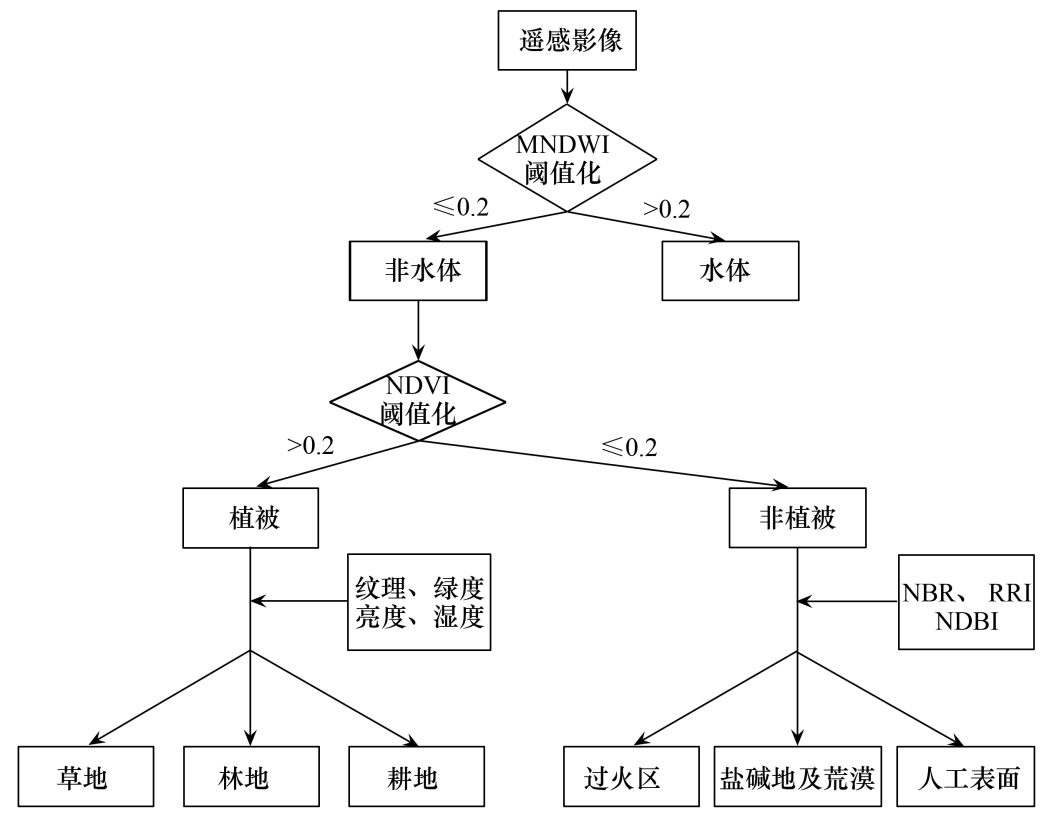

图 2 决策树示意图

Fig.2 Schematic diagram of decision tree

MNDWI: 归一化差异水体指数 NDVI: 归一化植被指数 RRI: 比值居民地指数 NDBI : 归一化建筑指数 NBR: 归一化燃烧率

\section{3 分类产品验证}

对研究区生成 1000 个随机点提取对应的分类结果类码,并利用 91 卫图系统里相应年份高空间分辨率图 像辅助目视解译结果作为参考值进行精度验证( 计算总体精度、用户精度、生产者精度和 Kappa 系数等精度 指标)。

\section{4 景观格局分析}

选取斑块数 $(N P)$ 、平均斑块面积 $(\mathrm{MPS})$ 、边界密度 $(E D)$ 和聚集度指数 $(A I) 4$ 个景观指数对研究区景观 进行分析。各景观指数的含义及其计算方法见表 2 。

2.5 土地利用状态转移模拟

\subsubsection{STSM 模型原理}

STSM 模型(State-and-transition Simulation Model)也是将景观空间划分为多个模拟单元组成的集合,这些 模拟单元虽然与栅格类似, 但可以是任意的形状和大小, 可有效避免其他预测模型管理状态空间过大的 问题 ${ }^{[21]}$ 。

图 3 展示了一种简单的森林植被状态转移模拟方法。景观整体被分割为多个模拟单元, 每个单元具有一 个初始状态 $(D=$ 落叶, $M=$ 混交, $C=$ 针叶 $)$ 和相应的年龄。每个单元都表现出转换状态方向。且随时间改变, 
每个单元的状态和年龄都发生了随机变化过程,这个过程是基于初始状态、年龄和转换概率进行模拟的。若 单元发生重叠, 在模拟结束时其状态和年龄都是单一的(图 3)。

\section{表 2 各景观指数列表}

Table 2 List of landscape indexes

\begin{tabular}{|c|c|c|}
\hline 分析指数 & 计算公式 & 说明 \\
\hline Analysis index & Calculation formula & Explanation \\
\hline $\begin{array}{l}\text { 斑块数 }(N P) \\
\text { Number of Patches }\end{array}$ & & 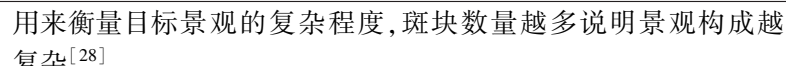 \\
\hline 平均斑块面积 (MPS) & & MPS 为平均斑块面积: $N P$ 为斑块数量: $T S$ 为评价区域总面积 \\
\hline Mean Patch Size & MPS $=\frac{N P}{T S}$ & 平均斑块面积越大说明景观较完整,破碎化程度较低 $[29]$ \\
\hline $\begin{array}{l}\text { 边界密度 }(E D) \\
\text { Edge Density }\end{array}$ & $E D=\frac{1}{A} \sum_{i=1}^{M} \sum_{j=1}^{M} P_{i j}$ & $\begin{array}{l}P_{i j} \text { :景观中第 } i \text { 类景观要素斑块与相邻第 } j \text { 类景观要素斑块间的 } \\
\text { 边界长度。边界密度越高说明斑块破碎化程度越高 }{ }^{[30]}\end{array}$ \\
\hline $\begin{array}{l}\text { 聚集度指数 }(A I) \\
\text { Aggregation Index }\end{array}$ & $A I=\frac{g_{i j}}{\max \left(g_{i j}\right)}$ & $\begin{array}{l}g_{i j} \text { : 相应景观类型的相似邻接斑块数量。聚集度指数越高说明景 } \\
\text { 观完整性较好, 相对的破碎化程度较低 }{ }^{311]}\end{array}$ \\
\hline
\end{tabular}

景观状态和年龄: $t=0$

\begin{tabular}{|l|l|l|l|l|l|l|l|}
\hline D5 & D4 & D4 & C21 & C22 & C22 & C23 & C24 \\
\hline D2 & D8 & D8 & M14 & C21 & C26 & C27 & C28 \\
\hline D1 & D3 & M11 & M12 & C22 & C26 & C28 & C30 \\
\hline D1 & D1 & D2 & M17 & M18 & M18 & C29 & C31 \\
\hline M19 & M18 & M18 & M17 & M19 & C32 & C33 & C36 \\
\hline M17 & M17 & M18 & D3 & D21 & D29 & D41 & D45 \\
\hline D8 & D7 & M19 & M18 & C22 & C22 & C28 & C36 \\
\hline D8 & M17 & M17 & M16 & M15 & C21 & C20 & C21 \\
\hline
\end{tabular}

景观状态和年龄: $t=40$

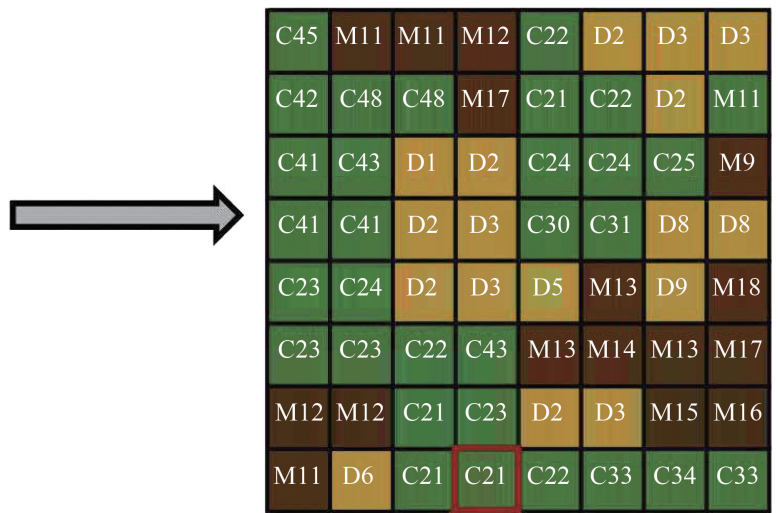

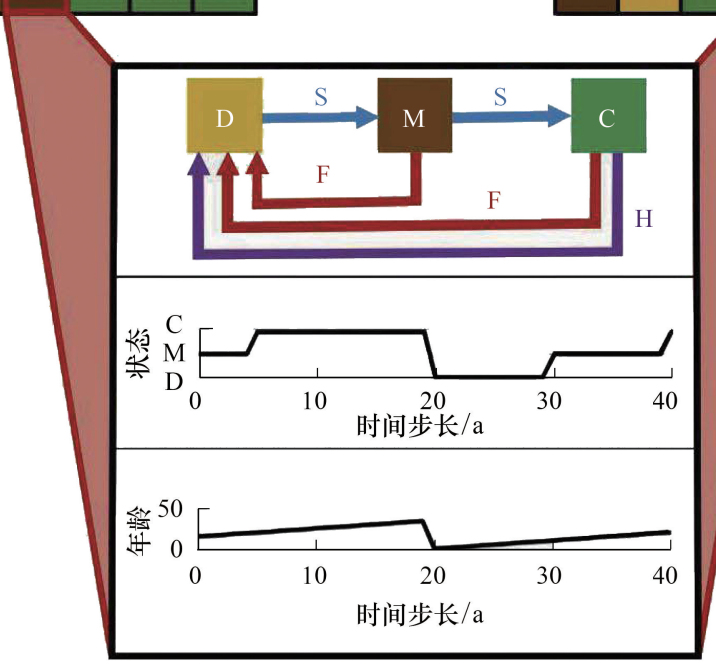

图 3 森林景观状态转移模拟模型原理图 ${ }^{[32-33]}$

Fig.3 Conceptual framework for simulating forest landscape transitions by state-and transition simulation model (STSM)

D: 落叶 Deciduous; M : 混交 Mixed;C: 针叶 Coniferous; S: 演替 Succession;F: 火烧 Fire;H:采伐 Harvest

\subsection{2 建立转换模型}

在 STSM 模型中需定义各土地类型之间的转换状态。本研究将这些过程定义为农田扩张和收缩、植被恢 复、城市化、草地恢复、林火和无转移这七种类型 (图 4) 
使用 2000 年和 2010 年的土地利用分类结果,计算 各转移类型的比例, 从而确定 STSM 模型中各类别的转 换概率, 并设置相近距离内发生概率的可能性, 确保模 拟发生位置的可靠性。将模拟出的 2018 年土地利用类 型与 2018 的真实分类进行空间一致性分析, 在满足精 度要求的前提下利用 2010 年和 2018 年土地利用分布 预测 2025 年的研究区土地利用空间模式。

\section{3 结果与分析}

\section{1 土地利用及变化分析}

分类精度验证结果表明, 2000、2010、2018 年土地 利用类型分类总体精度分别为 $89.12 \%, 89.60 \%$ 和 $90.40 \%$, Kappa 系数分别为 $0.8693,0.8717$ 和 0.8816 , 分 类结果精度较高,满足后续分析需求。

图 5 展示了 2010 年和 2018 年研究区土地利用分 类结果。观察图 5 可知,林地大部分集中在大兴安岭林 草交错带中的北部额尔古纳市及根河市, 东部的牙克石

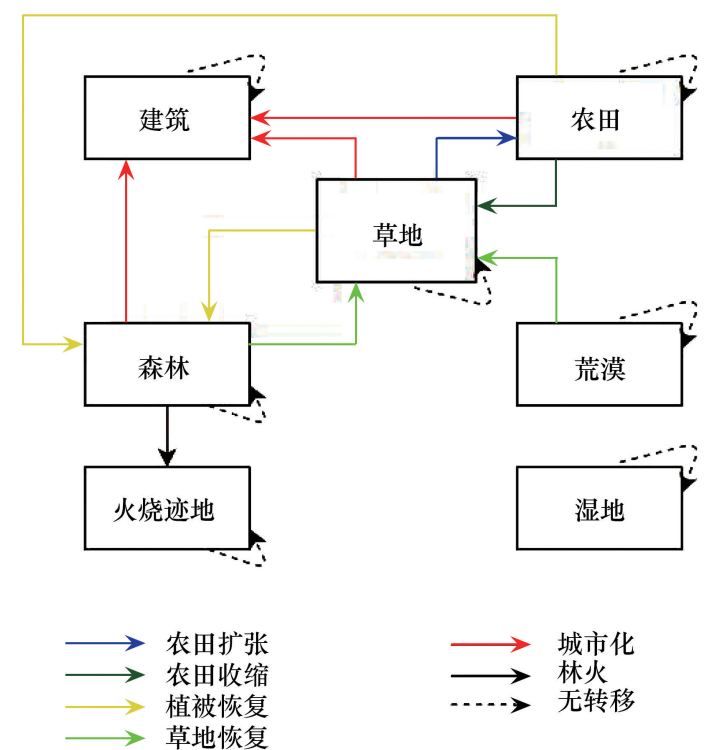

图 4 STSM 中土地利用转移规则定义

Fig.4 Land use transfer rules defined in STSM 市。草地位于大兴安岭西侧,集中分布在陈巴尔虎旗、新巴尔虎旗、鄂温克族自治旗和额尔古纳市南部。耕地 主要分布在草地森林交错过渡区域,耕地的地理位置随人类活动的城镇及周边河流水系紧密相连。湿地均匀 地分布在各个行政区,水系繁杂。研究区的城镇规模普遍较小,小城市占绝对比重, 居住分散,大量分布在以 海拉尔区为中心的周边县区内。此外, 道路作为城镇的重要组成部分, 与城镇的分布密切相关。道路遍布整 个研究区, 呈稀疏网状, 是大兴安岭林草交错带地区重要的交通和经济载体。荒漠主要分布于新巴尔虎左旗 和陈巴尔虎旗。

表 3 列举了研究区各土地利用类型的面积及对应比例。由表 3 可知,研究区各土地利用类型面积占比从 高到低依次为林地、草地、湿地、耕地、盐碱地及荒漠、人工表面和过火区。2010-2018 年间,城镇快速扩张、 工业高速发展, 导致人工表面面积迅速增长, 面积增加 $98.4 \mathrm{~km}^{2}$ 。与此同时耕地面积大量流失,面积减少 $36.47 \mathrm{~km}^{2}$ 。草地面积增长 $38.11 \mathrm{~km}^{2}$, 变化趋势与 2011 年推行的“退牧还草”政策相一致。林地面积减少 43 . $55 \mathrm{~km}^{2}$, 频繁的雷暴天气引发的林火是森林消失的主要原因 ${ }^{[34]}$ 。当地政府积极响应国家出台的沙化土地保 护政策,对出现退化、沙化、盐渍化等问题的草地及时采取管控措施,盐碱地及荒漠面积减少 $15.41 \mathrm{~km}^{2}$,草原 生态环境不断改善。

表 3 各土地利用类型面积

Table 3 Area of land use types

\begin{tabular}{lccccc}
\hline \multirow{2}{*}{$\begin{array}{l}\text { 类型 } \\
\text { Land-use type }\end{array}$} & \multicolumn{2}{c}{2010 年 } & & \multicolumn{2}{c}{2018 年 } \\
\cline { 2 - 3 } \cline { 5 - 6 } & $\begin{array}{c}\text { 面积 } \\
\text { Area } / \mathrm{km}^{2}\end{array}$ & $\begin{array}{c}\text { 百分比 } \\
\text { Percent } / \%\end{array}$ & & $\begin{array}{c}\text { 面积 } \\
\text { Area } / \mathrm{km}^{2}\end{array}$ & $\begin{array}{c}\text { 百分比 } \\
\text { Percent } / \%\end{array}$ \\
\hline 林地 Forest & 63016.29 & 46.93 & & 62972.74 & 46.89 \\
草地 Grassland & 42519.21 & 31.66 & & 42557.32 & 31.69 \\
耕田 Cropland & 6738.07 & 5.02 & 6701.60 & 4.99 \\
湿地 Wetland & 18434.80 & 13.73 & 18425.40 & 1546.80 & 13.72 \\
人工表面 Urban & 1448.40 & 1.08 & & 1.15 \\
盐碱地及荒漠 Saline-alkali lands and desert & 2079.03 & 1.55 & 2063.62 & 1.54 \\
过火区 Burned area & 52.47 & 0.04 & 20.79 & 0.02 \\
\hline
\end{tabular}




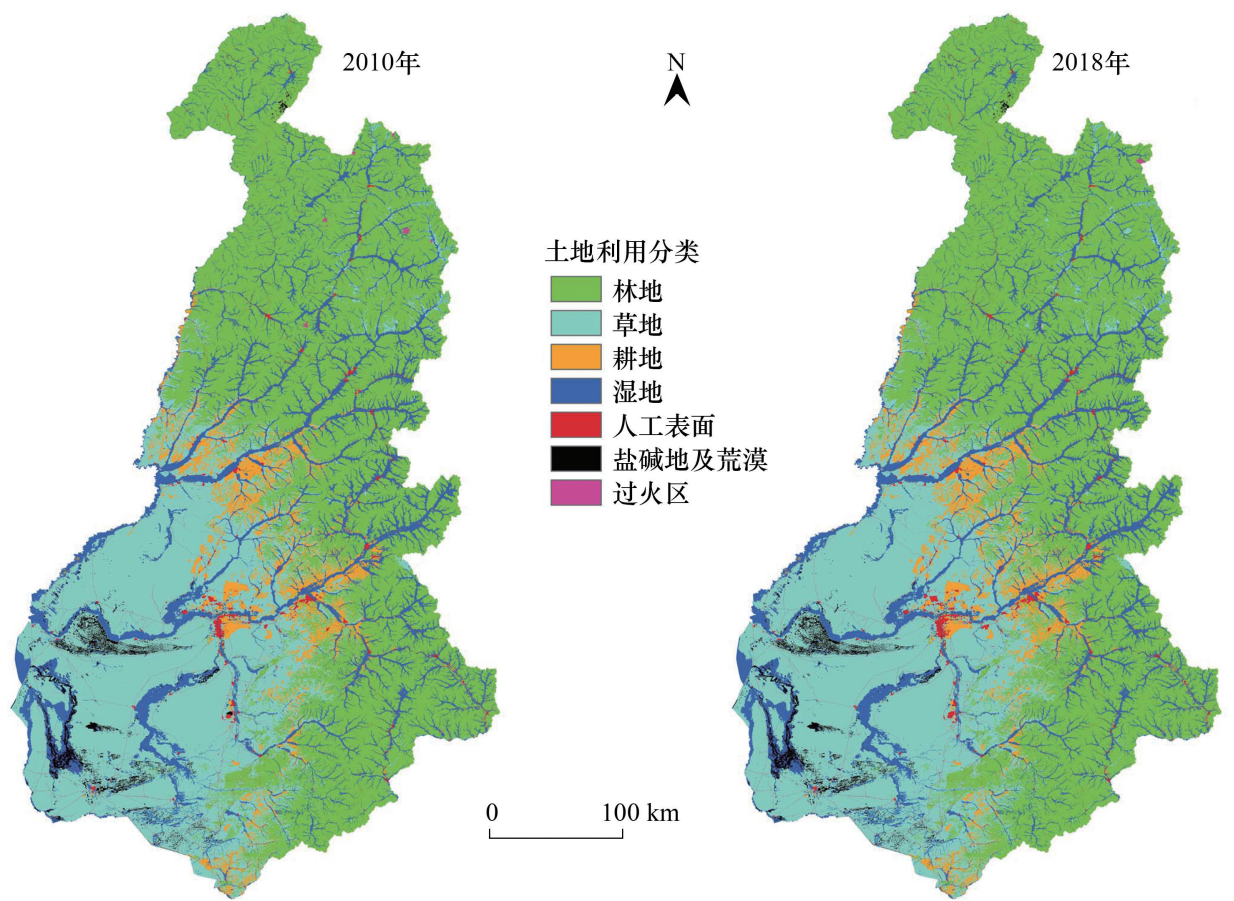

图 5 土地利用分类图

Fig.5 Land use classification maps

对比分析 2010-2018 年土地利用变化转移矩阵 (表 4), 研究区内土地利用类型未出现急剧变化的情形。 转出量最多的为过火区, 有 $51.70 \mathrm{~km}^{2}$ 转变成草地 (图 6)。大面积高强度火烧过后,一些速生型先锋草本、灌 木等迅速抢占生态位, 导致原有林型发生改变, 森林生态功能退化, 直接演变为草原。林地转出面积 46.78 $\mathrm{km}^{2}$, 其中 $13.38 \mathrm{~km}^{2}$ 转变为草地, $20.48 \mathrm{~km}^{2}$ 发生林火转变成过火区。转人面积最多的是人工表面, 总计 99.1 $\mathrm{km}^{2}$ 。2010 年前林区防火应急道路建设严重滞后,阻碍了林火综合防控能力的提升。2010 至 2018 年间林区 基础设施建设持续进行,约 $12.92 \mathrm{~km}^{2}$ 林地被用于林区道路建设。此外因城市扩张和道路建设,约 $27.41 \mathrm{~km}^{2}$ 草地转变成人工表面。

\section{表 $42010-2018$ 年土地利用变化转移矩阵}

Table 4 Transfer matrix of land use change from 2010 to 2018

\begin{tabular}{|c|c|c|c|c|c|c|c|}
\hline $\begin{array}{l}\text { 类型 } \\
\text { Land-use type }\end{array}$ & $\begin{array}{l}\text { 林地 } \\
\text { Forest }\end{array}$ & $\begin{array}{c}\text { 草地 } \\
\text { Grassland }\end{array}$ & $\begin{array}{c}\text { 耕地 } \\
\text { Cropland }\end{array}$ & $\begin{array}{c}\text { 湿地 } \\
\text { Wetland }\end{array}$ & $\begin{array}{c}\text { 人工表面 } \\
\text { Urban }\end{array}$ & $\begin{array}{l}\text { 盐碱地及荒漠 } \\
\text { Saline-alkali } \\
\text { lands and desert }\end{array}$ & $\begin{array}{c}\text { 过火区 } \\
\text { Burned area }\end{array}$ \\
\hline 林地 Forest & 62969.51 & 13.38 & 0 & 0 & 12.92 & 0 & 20.48 \\
\hline 草地 Grassland & 0 & 42487.37 & 3.26 & 0 & 27.41 & 1.17 & 0 \\
\hline 耕地 Cropland & 0 & 0 & 6697.71 & 0 & 40.35 & 0 & 0 \\
\hline 湿地 Wetland & 0 & 0 & 0.63 & 18424.85 & 9.32 & 0 & 0 \\
\hline 人工表面 Urban & 0 & 0.71 & 0 & 0 & 1447.70 & 0 & 0 \\
\hline $\begin{array}{l}\text { 盐碱地及荒漠 } \\
\text { Saline-alkali lands } \\
\text { and desert }\end{array}$ & 2.77 & 4.16 & 0 & 0.55 & 9.10 & 2062.45 & 0 \\
\hline 过火区 Burned area & 0.46 & 51.70 & 0 & 0 & 0 & 0 & 0.31 \\
\hline
\end{tabular}

3.2 区域景观格局变化分析

用 2018 与 2010 年的景观指数计算结果做差, 可得 2010-2018 年间研究区内景观格局变化情况 (表 5)。 


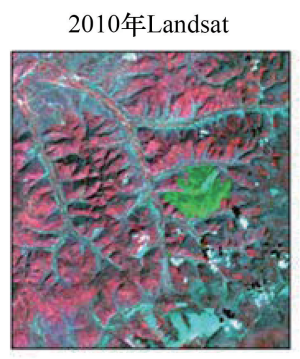

2010年Landsat

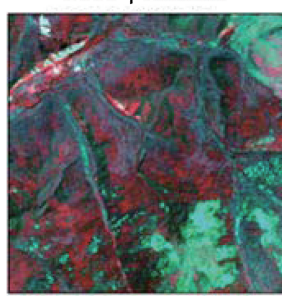

2010年Landsat

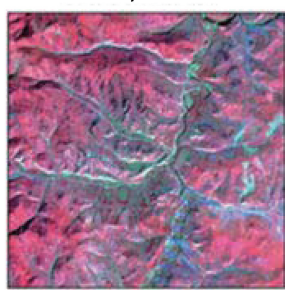

2010年Landsat

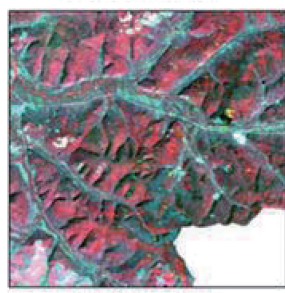

2010年Landsat

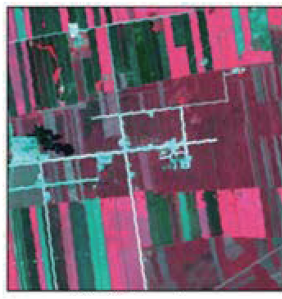

2010年Landsat

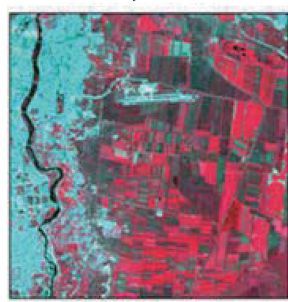

2018年Landsat

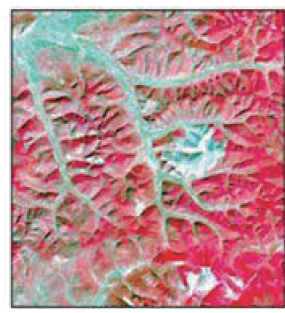

2018年Landsat

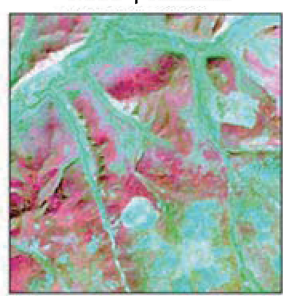

2018年Landsat

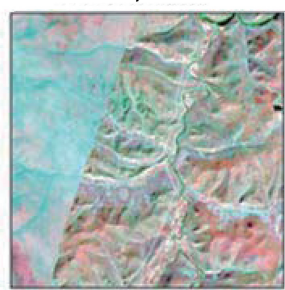

2018年Landsat

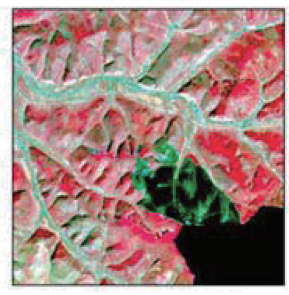

2018年Landsat

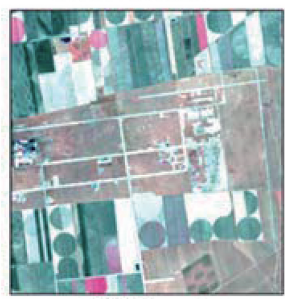

2018年Landsat

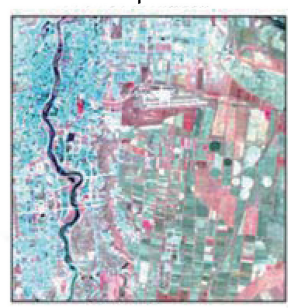

过火区变为草地

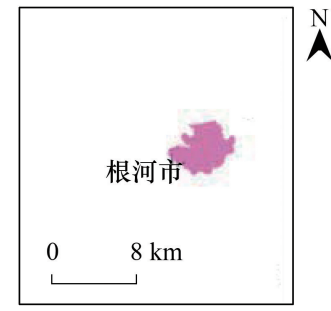

林地变为草地

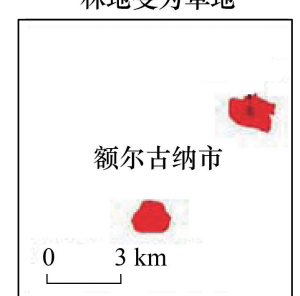

林地变为建设用地

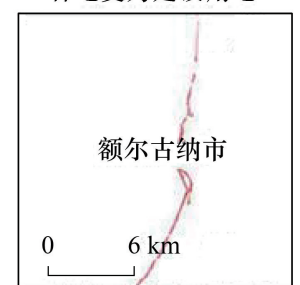

林地变为过火区

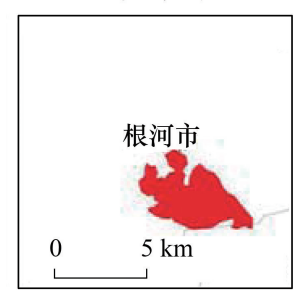

草地变为城市用地

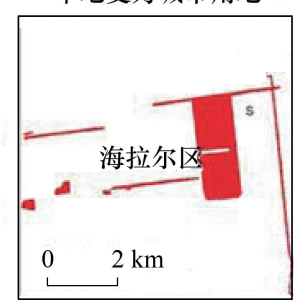

耕地变为城市建筑

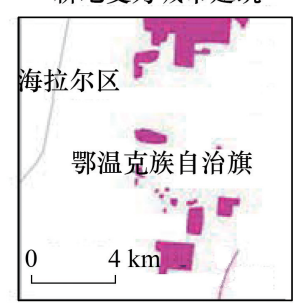

图 6 土地覆盖变化示意图

Fig.6 Schematic diagram of land cover change

从表 5 可知,在 2010-2018 年时间段内,林地类面积 $(C A)$ 减少 $4354.65 \mathrm{hm}^{2}$; 玟块数量增加 135 块,说明研究 区内林地景观构成趋于复杂; 边界密度 $(E D)$ 增加 $0.03 \mathrm{~m} / \mathrm{hm}^{2}$, 边界密度越高表明斑块破碎化程度越高, 故说 明林地破碎化程度有所提高; 平均斑块面积 (MPS) 减少 $1.3057 \mathrm{hm}^{2}$, 而每一类的斑块平均面积说明该类在景 
观中的完整性,林地类斑块平均面积的减少说明林地这一景观趋于不完整。草地和人工表面景观格局变化情 况均与林地相反,面积增加、破碎化程度降低、景观完整性提高。

表 52010 -2018 年研究区内景观格局变化

Table 5 Landscape pattern changes in the study area in 2010-2018

\begin{tabular}{lccccc}
\hline 类型 Land-use type & $C A / \mathrm{hm}^{2}$ & $N P /$ 个 & $E D /\left(\mathrm{m} / \mathrm{hm}^{2}\right)$ & $A I$ & $\mathrm{MPS} / \mathrm{hm}^{2}$ \\
\hline 林地 Forest & -4354.65 & 135 & 0.0300 & -0.0061 & -1.3057 \\
草地 Grassland & 3810.96 & -464 & 0.0075 & 0.0004 & 2.7172 \\
耕地 Cropland & -3646.35 & -33 & -0.0024 & -0.0279 & -0.1498 \\
湿地 Wetland & -940.68 & 119 & 0.0018 & -0.0040 & -0.6834 \\
人工表面 Urban & 9839.88 & -3205 & 0.0577 & 0.7157 & 13.1235 \\
盐碱地及荒漠 & -1540.80 & -74 & -0.0087 & -0.0379 & -0.0297 \\
Saline-alkali lands and desert & -3168.36 & -177 & -0.0100 & 0.5297 & 145.4862 \\
过火区 Burned area & & &
\end{tabular}

\section{3 土地利用模拟结果}

基于研究区 2000 和 2010 年土地利用分类图,利用 STSM 模型模拟 2018 年土地利用分类图 (图 7)。将实 际分类结果与模型模拟结果进行对比, 区域一致性达 $97.3 \%$,Kappa 系数为 0.96 , 表明本研究所建立的模拟模 型能够高精度地模拟研究区的土地利用格局。利用相同方法模拟得到 2025 年的土地利用分类图 (图 7)。

由预测结果 (表 6) 可知: 预计到 2025 年林地和草地面积分别增长 92.27、183.21 km²。大兴安岭林草交错 带分别于 1998 和 2011 年实施“天然林保护”工程和“退牧还草” 政策,草原生态各项指标显著提高。随着城 市化进程加快, 道路作为重要的经济交通载体和防火应急保障, 当地政府投人力度不断加大, 推动研究区人工 表面面积持续增长, 预计增长 $66.2 \mathrm{~km}^{2}$ 。受 “退耕还草” 政策的影响, 研究区耕地缓慢减少。此外, 盐碱地及

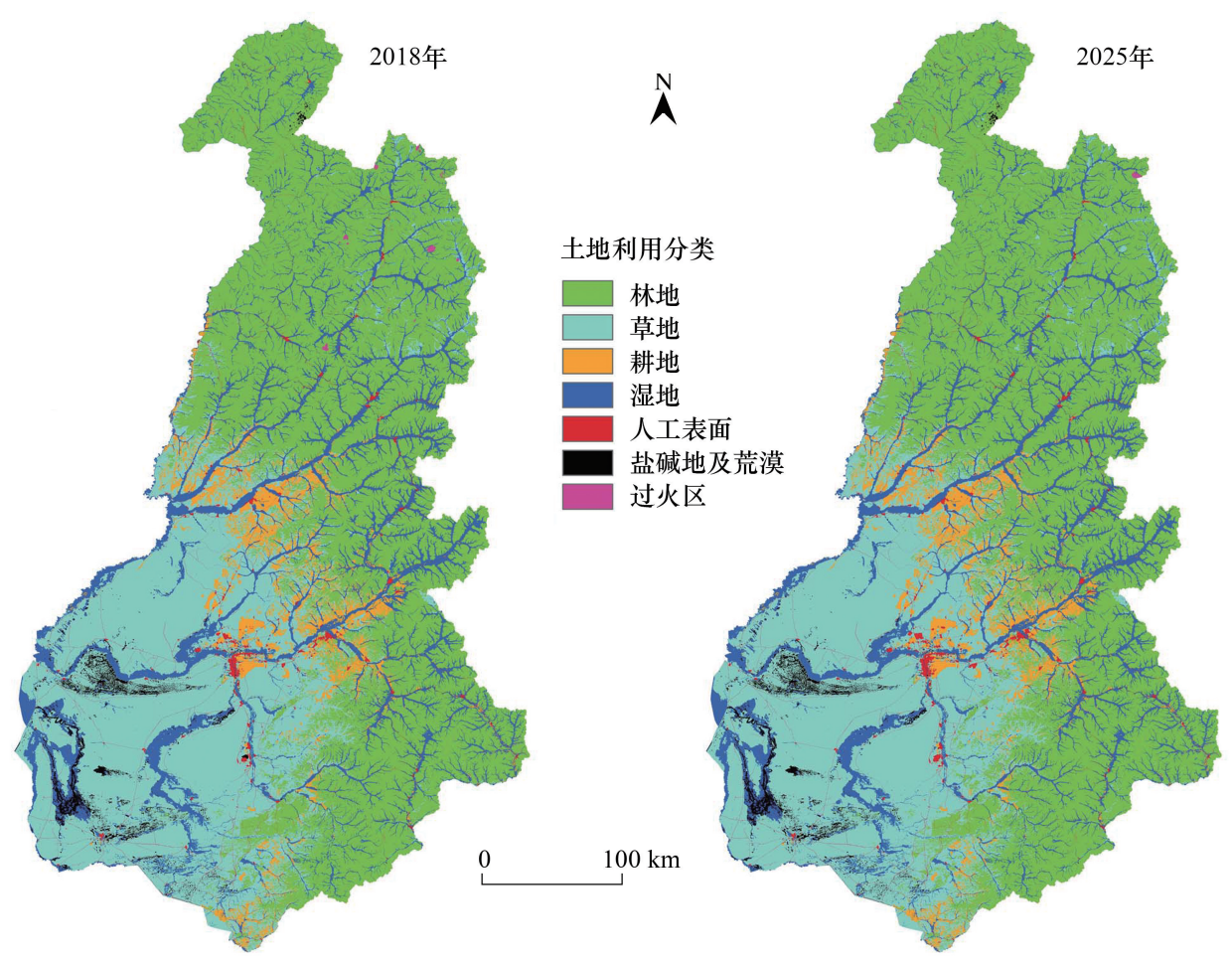

图 7 土地利用模拟图

Fig.7 Land use simulation maps 
荒地面积持续减少, 荒漠化治理成效显著。

表 6 STSM 模型预测结果 $/ \mathrm{km}^{2}$

Table 6 Land use prediction results from the STSM model

\begin{tabular}{|c|c|c|c|c|c|c|c|c|c|}
\hline $\begin{array}{l}\text { 类型 } \\
\text { Land-use type }\end{array}$ & $\begin{array}{c}2018 \text { 年 } \\
\text { 实际 } \\
\text { Truths }\end{array}$ & $\begin{array}{c}2018 \text { 年 } \\
\text { 预测 } \\
\text { Forecasts }\end{array}$ & $\begin{array}{c}2019 \text { 年 } \\
\text { 预测 } \\
\text { Forecasts }\end{array}$ & $\begin{array}{c}2020 \text { 年 } \\
\text { 预测 } \\
\text { Forecasts }\end{array}$ & $\begin{array}{c}2021 \text { 年 } \\
\text { 预测 } \\
\text { Forecasts }\end{array}$ & $\begin{array}{c}2022 \text { 年 } \\
\text { 预测 } \\
\text { Forecasts }\end{array}$ & $\begin{array}{c}2023 \text { 年 } \\
\text { 预测 } \\
\text { Forecasts }\end{array}$ & $\begin{array}{c}2024 \text { 年 } \\
\text { 预测 } \\
\text { Forecasts }\end{array}$ & $\begin{array}{c}2025 \text { 年 } \\
\text { 预测 } \\
\text { Forecasts }\end{array}$ \\
\hline 林地 Forest & 62972.74 & 63100.83 & 62988.54 & 63001.10 & 63013.86 & 63026.72 & 63039.56 & 63052.22 & 63065.01 \\
\hline 草地 Grassland & 42557.32 & 42727.81 & 42583.15 & 42609.56 & 42636.17 & 42661.79 & 42688.12 & 42714.51 & 42740.53 \\
\hline 耕地 Cropland & 6701.60 & 6527.82 & 6675.15 & 6648.75 & 6622.18 & 6596.31 & 6570.01 & 6543.75 & 6517.40 \\
\hline 湿地 Wetland & 18425.40 & 18431.92 & 18422.51 & 18422.51 & 18422.51 & 18422.51 & 18422.51 & 18422.51 & 18422.51 \\
\hline 人工表面 Urban & 1546.80 & 1524.39 & 1556.27 & 1565.67 & 1575.02 & 1584.60 & 1593.97 & 1603.43 & 1613.00 \\
\hline $\begin{array}{l}\text { 盐碱地及荒漠 } \\
\text { Saline-alkali lands and desert }\end{array}$ & 2063.62 & 1891.16 & 2040.22 & 2016.70 & 1993.09 & 1969.44 & 1945.79 & 1922.16 & 1898.78 \\
\hline 过火区 Burned area & 20.79 & 84.34 & 22.44 & 23.98 & 25.46 & 26.90 & 28.31 & 29.70 & 31.04 \\
\hline
\end{tabular}

\section{4 讨论}

4.1 基于面向对象的决策树分类结果的交叉验证

本研究生成的 3 期 $30 \mathrm{~m}$ 土地利用数据集,与 $\mathrm{Xu}$ 等 ${ }^{[35]}$ 生产的“中国 $30 \mathrm{~m}$ 逐年土地覆盖/土地利用数据集 (1980-2015)” (以下简称 CLUD-A) 相比,有以下几点区别。(1) 更高的分类精度。本研究采用面向对象的 决策树分类,结合辅助数据,得到的 3 期土地利用数据集精度均在 $85 \%$ 以上。而 CLUD-A 分类精度仅为 $75.61 \%$ 。(2)更详细的路网信息。在得到初步分类结果后,进行大量的目视解译纠错,研究区的路网信息得 到完整呈现 (例如, Landsat 影像无法自动分类刻画的低等级道路在本研究中可以被精细提取), 从而使得研究 区景观格局特征刻画更精准。(3) 湿地面积占比相对较大。由于分类体系的不同, 本研究将湿地森林和湿地 草原均分类为湿地,而 CLUD-A 分别分类为森林与草地, 因此本研究的湿地面积显著多于 CLUD-A。这样的 分类体系更加符合当地的管理需求 ${ }^{[36]}$ 。

\section{2 土地利用管理政策建议}

2025 年预测结果显示, 研究区过火区面积增加 $10.25 \mathrm{~km}^{2}$, 未来几年林火仍需大力防控。森林消防部门 可利用本研究提供的土地利用分类图,提取林火多发区路网信息,积极会同气象部门严查严控火灾源头,第一 时间展开科学扑救。此外,在过火区植被恢复过程中, 应当根据破坏程度 ${ }^{[34]}$ 、立地条件、资源经营条件合理分 级分类, 将植被自然更新恢复和人工干预恢复有机结合 ${ }^{[7]}$, 科学有效地缩短植被恢复到顶级群落所需要的时 间, 全面提高大兴安岭林草交错带过火区植被的恢复速度和恢复质量。研究结果显示, 在新巴尔虎旗北部地 区仍存在大面积沙化土地。当地管理部门应积极响应国家出台的沙化土地保护政策,加快制定本地区的防治 草原荒漠化治理政策。对于部分出现退化、沙化、盐渍化等问题的草地应该及时采取管控措施,如推行围栏封 育、轮封轮牧, 加快优良畜种培育、优化畜种结构 ${ }^{[36]}$, 实现草原生态保护和农牧民增收的双赢目标。

\subsection{STSM 模型应用前景及局限性}

STSM 模型在转换概率的选择上是通过增加一定的距离要素以及定义其他相关因子确定的。相对于 CAMarkov 模型,STSM 模型主观因素更多,可以根据历史条件使得模拟结果更加精确。但由于其过于主观, 缺乏 一定的地理空间位置模拟, 仅在具有历史数据且大尺度区域的研究中占有优势。陈倩 ${ }^{[21]}$ 利用 CA-Markov 和 STSM 模型模拟预测了南京市老山国家森林公园 2016 年的土地覆盖状况。结果显示 CA-Markov 模型总体预 测精度为 $75.17 \%$, 而 STSM 模型仅为 $71.55 \%$ 。表明针对小范围高分辨率空间数据的 CA-Markov 模型预测效 果更好, 可信度更高。本研究的研究区面积达 13.43 万 $\mathrm{km}^{2}$, 选取 STSM 模型模拟得到的 2018 年土地利用分 类图区域一致性达 $97.3 \%$,Kappa 系数 0.96 , 表明本研究所建立的模型能够较好地模拟研究区的土地利用格 局。不足之处在于, 未来的土地利用变化还会受到气候变化等更多因素的影响, 本文尚未考虑这些因素, 未来 
的研究需进一步探索。

\section{5 结论}

(1) 大兴安岭林草交错带 2010-2018 年间的景观生态环境动态变化主要表现为林火导致的森林草地 化、草原耕地化、低盖度草地荒漠化以及林草田人居化。人类行为与自然反馈相互影响的结果在林草交错生 态脆弱区的生态环境变化中表现得尤为明显。城市用地和路网的迅速扩张、草地大面积开怎以及气象灾害引 发的林火都对研究区的生态环境造成巨大影响。

(2) 景观尺度上,研究区内的林地在 2010-2018 年期间,面积减少、破碎化程度增大、景观完整性降低、 景观构成愈发复杂; 草地面积增加、景观完整性升高; 耕地面积减少、破碎化程度增高, 景观完整性降低; 人工 表面面积大幅度增加、破碎化程度降低,景观完整性升高。

(3) 在现行土地利用发展趋势下,预测 2025 年研究区林地、草地、人工表面和过火区面积分别增加 92.27 、 183.21、66.2 $\mathrm{km}^{2}$ 和 $10.25 \mathrm{~km}^{2}$; 耕地和盐碱地及荒漠面积分别减少 $184.2 \mathrm{~km}^{2}$ 和 $164.84 \mathrm{~km}^{2}$ 。湿地面积相对稳 定,无较大变化。

\section{参考文献 (References) :}

[1] 张宇硕, 吴殿廷, 吕晓. 土地利用/覆盖变化对生态系统服务的影响：空间尺度视角的研究综述. 自然资源学报，2020，35(5)： 1172-1189

[ 2 ] 张娟, 陈凡, 角媛梅, 刘澄静, 赵冬梅, 刘志林, 徐秋娥, 邱应美. 哈尼梯田区不同旅游模式村寨土地利用变化对生态系统服务与人类福 利的影响. 生态学报, 2020, 40(15) : 5179-5189.

[ 3 ] 刘硕, 李品, 冯兆忠. 京津冀防风固沙植被生态修复研究进展与对策. 生态学杂志, 2019, 38(1): 267-274.

[ 4 ] 李茂华, 都金康, 李皖粀, 李闰洁, 吴森圭, 王姗姗. 1982-2015 年全球植被变化及其与温度和降水的关系. 地理科学, 2020, 40(5)： 823-832.

[ 5 ] 文志, 郑华, 欧阳志云. 生物多样性与生态系统服务关系研究进展. 应用生态学报, 2020, 31 (1) : 340-348.

[ 6 ] 薛佳金金, 刘鸿雁, 许重阳, Anenkhonov O A, Sandanov D V, Korolyuk A Y, 蒋子涵, 柳絮, Balsanova L D, Naidanov B. 树木管胞大小对于 西伯利亚南部林草交错带森林生长及环境适应性的指示意义. 北京大学学报: 自然科学版, 2020, 56(3) : 531-538.

[ 7 ] 魏琦. 北方农牧交错带生态脆弱性评价与生态治理研究——内蒙古林西县为例 [D]. 北京: 中国农业科学院, 2010.

[ 8 ] 车通, 李成, 罗云建. 城市扩张过程中建设用地景观格局演变特征及其驱动力. 生态学报, 2020, 40(10): 3283-3294.

[9] 周亚军, 刘廷胥, 段利民, 王怡璇, 李霞, 黎明扬. 锡林河流域上游河谷湿地景观格局演变及其驱动力. 干旱区研究, 2020, 37( 3 ) : 580-590.

[10] 乔斌, 祝存兄, 曹晓云, 肖建设, 扎西拉旦, 颜玉倩, 陈国茜, 史飞飞. 格网尺度下青海玛多县土地利用及生态系统服务价值空间自相关 分析. 应用生态学报, 2020, 31(5): 1660-1672.

[11] 马珂, 王智, 吴友均, 周月明, 师庆东. 基于马尔柯夫过程的干旱区景观生态环境动态分析一一以新疆乌苏绿洲为例. 新疆农业科学, 2011, 48(5) : 954-961.

[12］吕乐婷, 张杰, 彭秋志, 任斐鹏, 江源. 东江流域景观格局演变分析及变化预测. 生态学报, 2019, 39(18) : 6850-6859.

[13］叶晶萍, 刘士余, 盛菲, 刘政, 杨敏, 李俊. 寻乌水流域景观格局演变及其生态环境效应. 生态学报, 2020, 40(14) : 4737-4748.

[14] Keller A A, Fournier E, Fox J. Minimizing impacts of land use change on ecosystem services using multi-criteria heuristic analysis. Journal of Environment Management, 2015, 156: 23-30.

[15] 何丹, 金凤君, 周璟. 基于 Logistic-CA-Markov 的土地利用景观格局变化一一京津冀都市圈为例. 地理科学, 2011, 31(8): 903-910.

［16］郑青华, 罗格平, 朱䂺, 周德成. 基于 CA-Markov 模型的伊犁河三角洲景观格局预测. 应用生态学报, 2010, 21(4): 873-882.

[17］杨国清, 刘耀林, 吴志峰. 基于 CA-Markov 模型的土地利用格局变化研究. 武汉大学学报: 信息科学版, 2007, 32(5): 414-418.

[18］姜广辉, 张凤荣, 孔祥斌. 北京山区农村居民点整理用地转换方向模拟. 农业工程学报, 2009, 25(2): 214-221.

[19］马梓策, 于红博, 张巧凤，曹聪明. 基于 CA-Markov 模型的锡林河流域土地利用变化及预测分析. 西北林学院学报，2020，35(2)： 169- 177.

[20] Guan D J, Li H F, Inohae T, Su W C, Nagaie T, Hokao K. Modeling urban land use change by the integration of cellular automaton and Markov model. Ecological Modelling, 2011, 222(20/22) : 3761-3772.

[21］陈倩. 城市化进程下土地覆盖、森林空间模式及属性变化分析一一南京老山国家森林公园为例 [ D ]. 南京: 南京林业大学, 2018. 
[22] 徐涵秋. 利用改进的归一化差异水体指数 (MNDWI) 提取水体信息的研究. 遥感学报, 2005, 9(5): 589-595.

[23] D' Iorio M A, Cihlar J. Relationship between AVHRR NDVI and environmental parameters//Proceedings of the 12th Canadian Symposium on Remote Sensing Geoscience and Remote Sensing Symposium. Vancouver, BC, Canada: IEEE, 1989.

[24] 吴宏安, 蒋建军, 张海龙, 张丽, 周杰. 比值居民地指数在城镇信息提取中的应用. 南京师大学报: 自然科学版, 2006, 29(3): 118-121.

[25］查勇, 倪绍祥, 杨山. 一种利用 TM 图像自动提取城镇用地信息的有效方法. 遥感学报, 2003, 7(1): 37-40.

[26] 罗开盛, 李仁东. 基于 $\mathrm{HJ}$ 影像的面向对象土地覆被分类方法. 华中师范大学学报: 自然科学版, 2013, 47(4) : 565-570, 577-577.

[27] García M J L, Caselles V. Mapping burns and natural reforestation using thematic Mapper data. Geocarto International, 1991, 6(1) : 31 - 37.

[28］陈文波，肖笃宁，李秀珍. 景观指数分类、应用及构建研究. 应用生态学报, 2002, 13(1): 121-125.

[29］全川, 吴雅琼, 龚建周. 内蒙古和林格尔农牧交错区景观特征与景观管理. 水土保持学报, 2003, 17(2): 114-117.

[30］周年兴, 黄震方, 蒋铭萍, 梁艳艳. 庐山森林景观美学质量与景观格局指数的关系. 地理研究, 2012, 31(7): 1224-1232.

[31] 姚侠妹, 偶春, 钟超, 韩保军. 地方院校校园绿地景观格局指数评析一以阜阳师范学院为例. 阜阳师范学院学报: 自然科学版, 2012, $29(4)$ : 33-39.

[32] Daniel C J, Frid L, Sleeter B M, Fortin M J. State-and-transition simulation models: a framework for forecasting landscape change. Methods in Ecology and Evolution, 2016, 7(11): 1413-1423.

[33] Sleeter B M, Wilson T S, Sharygin E, Sherba J T. Future scenarios of land change based on empirical data and demographic trends. Earth's Future, 2017, 5(11): 1068- 1083.

[34］谭柳霞，曾永年, 郑忠. 林火烈度遥感评估指数适应性分析. 国土资源遥感, 2016, 28(2) : 84-90.

[35] Xu Y D, Yu L, Peng D L, Zhao J Y, Cheng Y Q, Liu X X, Li W, Meng R, Xu X L, Gong P. Annual 30-m land use/land cover maps of China for 1980 - 2015 from the integration of AVHRR, MODIS and Landsat data using the BFAST algorithm. Science China Earth Sciences, 2020, 63 (9) : 1390-1407.

[36] 孔祥智, 安晓宁, 魏虹. 内蒙古呼伦贝尔草原保护的对策研究. 理论研究, 2001, (5) : 15-18. 